Article

\title{
Controlled and Efficient Polymerization of Conjugated Polar Alkenes by Lewis Pairs Based on Sterically Hindered Aryloxide- Substituted Alkylaluminum
}

\author{
Xiaojun Wang, Yixin Zhang and Miao Hong * \\ State Key Laboratory of Organometallic Chemistry, Center for Excellence in Molecular Synthesis, \\ Shanghai Institute of Organic Chemistry, University of Chinese Academy of Sciences, \\ Chinese Academy of Sciences, 345 Lingling Road, Shanghai 200032, China; wangxiaojun@sioc.ac.cn (X.W.); \\ zhangyixin1@sioc.ac.cn (Y.Z.) \\ * Correspondence: miaohong@sioc.ac.cn; Tel.: +86-21-5492-5610
}

Received: 30 January 2018; Accepted: 14 February 2018; Published: 17 February 2018

\begin{abstract}
Reported herein is the development of an effective strategy for controlled and efficient Lewis pair polymerization of conjugated polar alkenes, including methyl methacrylate (MMA), $n$-butyl methacrylate ( $\left.{ }^{n} \mathrm{BuMA}\right)$, and $\gamma$-methyl- $\alpha$-methylene- $\gamma$-butyrolactone ( $\left.\gamma \mathrm{MMBL}\right)$, by the utilization of sterically encumbered $\mathrm{Al}(\mathrm{BHT})_{2} \mathrm{Me}$ (BHT: 2,6-di-tert-butyl-4-methylphenol) as a Lewis acid that shuts down intramolecular backbiting termination. In combination with a selected $N$-heterocyclic carbene (NHC) as a Lewis base, the polymerization of MMA exhibited activity up to $3000 \mathrm{~h}^{-1}$ TOF and an acceptable initiation efficiency of $60.6 \%$, producing polymers with high molecular weight $\left(M_{\mathrm{n}}\right.$ up to $130 \mathrm{~kg} / \mathrm{mol})$ and extremely narrow dispersity $(\nexists=1.06 \sim 1.13)$. This controlled polymerization with a living characteristic has been evidenced by chain-extension experiments and chain-end analysis, and enabled the synthesis of well-defined diblock copolymers.
\end{abstract}

Keywords: frustrated Lewis pair; Lewis pair; polymerization; carbenes; acrylics

\section{Introduction}

Lewis pair polymerization (LPP), catalyzed by frustrated Lewis pairs (FLPs) [1-5] or classical Lewis pairs (CLPs) in which Lewis acid (LA) and Lewis base (LB) are involved in monomer substrate activation, chain initiation, as well as chain propagation and termination/transfer steps (Scheme 1A) [6], has recently emerged and attracted enormous interest because the cooperation of a Lewis pair (LP) allows for polymerization that is hardly accessible using a single catalyst and enhances the activity and selectivity of this polymerization. The pioneering work of LPP was first reported by Chen et al. in 2010 utilizing FLPs or CLPs consisting of bulky phosphine or an N-heterocyclic carbene (NHC) LB and the highly acidic $\mathrm{Al}\left(\mathrm{C}_{6} \mathrm{~F}_{5}\right)_{3} \mathrm{LA}$, which are capable of promoting rapid polymerization of conjugated polar alkenes, such as methyl methacrylate (MMA) and biorenewable $\gamma \mathrm{MMBL}$ (turnover frequency (TOF) [7] up to $48,000 \mathrm{~h}^{-1}$ ) [8]. In their latter contributions, this unique catalytic system was extended to the polymerization of other acrylate and acrylamide derivatives [9] as well as monomers with $\mathrm{C}=\mathrm{C}-\mathrm{C}=\mathrm{N}$ functionality such as 2-vinyl pyridine and 2-isopropenyl-2-oxazoline [10]. Recently, the highly active LPP of $\gamma$ MMBL by metal-free $B\left(\mathrm{C}_{6} \mathrm{~F}_{5}\right)_{3}$-based LA in combination with NHC or phosphine LB was investigated by Chen et al., who found that interacting LPs or even CLPs are essential for highly effective polymerization, whereas the B/P FLP systems exhibit no or negligible polymerization reactivity [11-13]. In 2014, Lu and colleagues reported the chemoselective polymerization of dissymmetric divinyl acrylic monomers by $\mathrm{Al}\left(\mathrm{C}_{6} \mathrm{~F}_{5}\right)_{3}$-based CLPs, affording soluble polymers with high molecular weight for post-functionalization [14]. Very recently, $\mathrm{Xu}$ and 
coworkers developed intramolecular and intermolecular rare-earth $(\mathrm{RE}=\mathrm{Sc}, \mathrm{Y}, \mathrm{Lu}, \mathrm{La}) /$ phosphine LPs for the polymerization of MMA, $\gamma \mathrm{MMBL}$, and other acrylate derivatives [15,16]. Besides the conjugated-addition polymerization of polar alkenes, controlled ring-opening (co)polymerizations of heterocyclic monomers such as lactide, lactones, and $\alpha$-amino acid $N$-carboxy-anhydride, as well as the alternating ring-opening copolymerization of epoxides with carbonyl sulfide or cyclic anhydrides, have been achieved with $\mathrm{BEt}_{3}, \mathrm{~B}\left(\mathrm{C}_{6} \mathrm{~F}_{5}\right)_{3}, \mathrm{Al}\left(\mathrm{C}_{6} \mathrm{~F}_{5}\right)_{3}$ and $\mathrm{Zn}\left(\mathrm{C}_{6} \mathrm{~F}_{5}\right)_{2}$-based LPs [17-25].

Controlled polymerization with a living characteristic is a powerful strategy for the precise control of macromolecular structure, which enables the addition of functionality to materials for practical applications [26-32]. Though exciting results have been achieved in the LPPs of conjugated polar alkenes, these polymerizations were unfortunately difficult to control, presumably due to undesired chain termination proceeding via intramolecular backbiting to generate a six-membered lactone (Scheme 1A) [33-35]. To avoid chain termination, the strategy reported in the literatures has been the utilization of weak acidic LAs, which weakens the activation of adjacent ester groups of the growing polymer chain, thereby suppressing the backbiting reaction. However, the controlled LPP via this strategy is usually at the expense of polymerization activity, as the weak acidic LA also impairs the activation of monomers, thus leading to slow propagation. For example, Rieger and co-workers reported a controlled LPP of $N, N$-dimethylacrylamide (DMAA) and methylacrylate derivatives, such as furfuryl methacrylate (FMA), ${ }^{n}$ BuMA, and $t$-butyl methacrylate ( ${ }^{t}$ BuMA), via highly interacting CLPs composed of weak acidic organoaluminum LAs $\left(\mathrm{AlMe}_{3}\right.$ and $\left.\mathrm{AlEt}_{3}\right)$ and less sterically hindered phosphines $\left(\mathrm{PMe}_{3}\right.$ and $\mathrm{PEt}_{3}$ ), but the polymerization activity was relatively low (TOF: 67 500 h⿱一土 ${ }^{-1}$ [36]. Likewise, Taton et al. established a controlled but low active polymerization of MMA $\left(\mathrm{TOF}<14.3 \mathrm{~h}^{-1}\right)$ via metal-free LPs composed of a weak silane LA ( $\left.\mathrm{Me}_{3} \mathrm{SiNTf}_{2}, \mathrm{Me}_{3} \mathrm{SiOTf}\right)$ and phosphine LB [37].

As shown by the above overview, the development of an effective LPP of conjugated polar alkenes that not only exhibits good activity but also has a high degree of control over the polymerization has remained elusive and is the central goal of this study. In this context, we set out to examine the LPPs toward three representative acrylic monomers, including MMA, ${ }^{n} \mathrm{BuMA}$, and $\gamma \mathrm{MMBL}$ using $\mathrm{Al}(\mathrm{BHT})_{2} \mathrm{Me}$ as an LA (Scheme $\left.1 \mathrm{~B}\right)$, which is more sterically hindered but slightly less Lewis-acidic compared to commonly used $\mathrm{Al}\left(\mathrm{C}_{6} \mathrm{~F}_{5}\right)_{3}$. We envisioned that the introduction of such a sterically encumbered LA would block intramolecular backbiting termination (Scheme 1B); furthermore, we figured that the LA's suitable Lewis acidity as well as the utilization of a strong nucleophile NHC ( ${ }^{(\mathrm{Ph}) \mathrm{Et}} \mathrm{NHC},{ }^{i \operatorname{Pr}} \mathrm{NHC}$, and $\left.{ }^{t \mathrm{Bu}} \mathrm{NHC}\right)$ would ensure good activity and thus would present an opportunity for efficient and controlled polymerization.

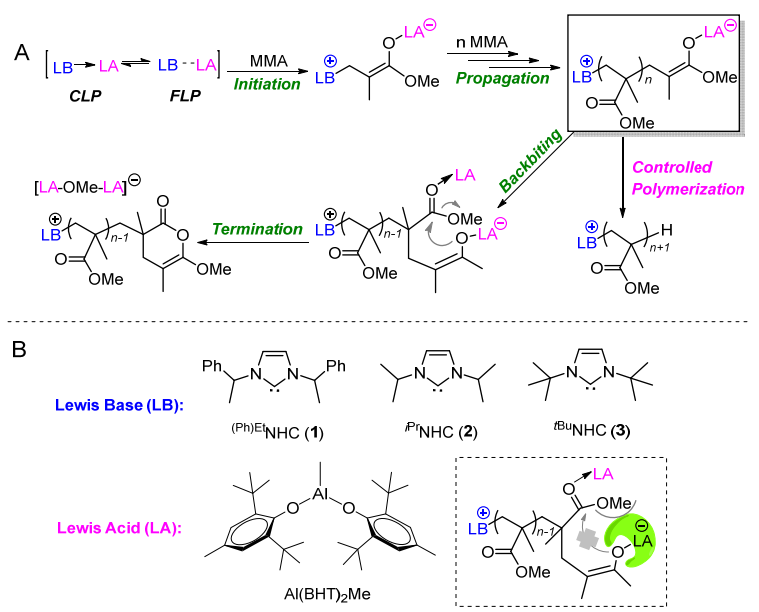

Scheme 1. (A) Generalized chain initiation, propagation, and termination mechanisms of the Lewis pair polymerization (LPP) of methyl methacrylate (MMA) through zwitterionic intermediates. (B) The structures of Lewis acids (LAs) and Lewis bases (LBs) examined in this study. 


\section{Results and Discussion}

\subsection{Interaction of $\mathrm{Al}(\mathrm{BHT})_{2} \mathrm{Me}$ with ${ }^{(\mathrm{Ph}) \mathrm{Et}} \mathrm{NHC}$}

The reactivity of the selected NHC ( $\left.\left.{ }^{\mathrm{Ph}}\right) \mathrm{Et} \mathrm{NHC}\right)$ toward equivalent $\mathrm{Al}(\mathrm{BHT})_{2} \mathrm{Me}$ was examined at the NMR scale in J-Young NMR tube using bezene- $\mathrm{d}_{8}$ as the solvent at room temperature (RT). ${ }^{1} \mathrm{H}-\mathrm{NMR}$ analysis revealed that the reaction between ${ }^{(\mathrm{Ph}) \mathrm{Et}} \mathrm{NHC}$ and $\mathrm{Al}(\mathrm{BHT})_{2} \mathrm{Me}$ was rapid, which was completed in $10 \mathrm{~min}$, affording a clean ${ }^{(\mathrm{Ph}) \mathrm{Et}} \mathrm{NHC} \rightarrow \mathrm{Al}(\mathrm{BHT})_{2} \mathrm{Me}$ CLP adduct. The characteristic signals corresponding to the $>\mathrm{CHCH}_{3}$ group of the ${ }^{(\mathrm{Ph}) \mathrm{Et}} \mathrm{NHC}$ were downfield-shifted by around $0.6 \mathrm{ppm}$ after the reaction, which is indicative of the strong donation of electron density from the carbene center to the Lewis-acidic Al center. Interestingly, two sets of signals can be observed for the $>\mathrm{CHCH}_{3}$ and $-\mathrm{CH}=\mathrm{CH}-$ groups of ${ }^{(\mathrm{Ph}) \mathrm{Et}} \mathrm{NHC}$ with a ratio of around 6:4, indicating that the resultant adduct contains two isomers, presumably caused by the constrained geometry of ${ }^{(\mathrm{Ph}) \mathrm{Et}} \mathrm{NHC}$ in the adduct due to the sterically hindered $\mathrm{Al}(\mathrm{BHT})_{2} \mathrm{Me}$. The stoichiometric reaction of $\mathrm{Al}(\mathrm{BHT})_{2} \mathrm{Me}$ with $\mathrm{MMA}$ was also investigated in the bezene- $\mathrm{d}_{8}$ by ${ }^{1} \mathrm{H}-\mathrm{NMR}$. Most significantly, the signals attributed to the MMA shifted upfield $\left(=\mathrm{CH}_{2}: 5.11 \mathrm{ppm},-\mathrm{OCH}_{3}: 3.17 \mathrm{ppm},-\mathrm{CH}_{3}: 1.39 \mathrm{ppm}\right)\left(\right.$ exception: $\left.=\mathrm{CH}_{2}: 6.20 \mathrm{ppm}\right)$ relative to free $\mathrm{MMA}\left(=\mathrm{CH}_{2}: 6.07\right.$ and $\left.5.19 \mathrm{ppm},-\mathrm{OCH}_{3}: 3.36 \mathrm{ppm},-\mathrm{CH}_{3}: 1.80 \mathrm{ppm}\right)$, suggesting the formation of $\mathrm{MMA} \rightarrow \mathrm{Al}(\mathrm{BHT})_{2} \mathrm{Me} \mathrm{CLP}$ adduct and the ability of $\mathrm{Al}(\mathrm{BHT})_{2} \mathrm{Me}$ to activate MMA. In contrast, the signals of MMA was shifted upfield even further $\left(=\mathrm{CH}_{2}: 5.85\right.$ and $4.98 \mathrm{ppm},-\mathrm{OCH}_{3}$ : 3.11 ppm, $\left.-\mathrm{CH}_{3}: 1.30 \mathrm{ppm}\right)$ when coupled with $\mathrm{Al}\left(\mathrm{C}_{6} \mathrm{~F}_{5}\right)_{3}$ [8], which is consistent with the fact that the Lewis acidity of $\mathrm{Al}(\mathrm{BHT})_{2} \mathrm{Me}$ is weaker than that of $\mathrm{Al}\left(\mathrm{C}_{6} \mathrm{~F}_{5}\right)_{3}$. We also tried to detect the zwitterionic imidazolium enolaluminate intermediate by the reaction of $\mathrm{MMA} \rightarrow \mathrm{Al}(\mathrm{BHT})_{2} \mathrm{Me}$ with ${ }^{(\mathrm{Ph}) \mathrm{Et}} \mathrm{NHC}$ at RT in bezene- $\mathrm{d}_{8}$. However, ${ }^{1} \mathrm{H}-\mathrm{NMR}$ spectrum after the reaction was very complex and the signals attributed to zwitterionic imidazolium enolaluminate were undetectable, though the signals corresponding to $\mathrm{MMA} \rightarrow \mathrm{Al}(\mathrm{BHT})_{2} \mathrm{Me}$ and ${ }^{(\mathrm{Ph}) \mathrm{Et}} \mathrm{NHC}$ vanished, presumably a result of the limited stability of zwitterionic intermediate at RT in the absence of a monomers.

\subsection{Characteristic of Polymerization by $\mathrm{NHC} / \mathrm{Al}(\mathrm{BHT})_{2} \mathrm{Me}$}

The initial investigation was carried out using an $\mathrm{Al}(\mathrm{BHT})_{2} \mathrm{Me} \mathrm{LA} \mathrm{or}{ }^{(\mathrm{Ph}) \mathrm{Et}} \mathrm{NHC}$ LB alone for polymerization of MMA at RT in toluene, and these control runs yielded no polymer formation for up to $24 \mathrm{~h}$ (Table 1, Runs 1 and 2). Intriguingly, the polymerization became highly active when premixing $\mathrm{Al}(\mathrm{BHT})_{2} \mathrm{Me}$ with MMA in toluene followed by the addition of (Ph)Et $\mathrm{NHC}$ to start the polymerization, which can convert all monomers into polymers in $3 \mathrm{~min}$ (TOF $=2000 \mathrm{~h}^{-1}$, Table 1 , Run 3 ), which is consistent with the bimolecular, activated monomer mechanism proposed for LPPs in the literature. In sharp contrast, no polymerization was observed when the $\mathrm{Al}(\mathrm{BHT})_{2} \mathrm{Me} \mathrm{LA}$ was coupled with $\mathrm{P}^{t} \mathrm{Bu}_{3}$ LB [9], demonstrating that the cooperation of LA and LB components is critical to the reactivity of LPPs. Note that the dispersity of the obtained PMMA was very narrow $(\bigoplus=1.11)$, despite the fact that the resulting $M_{\mathrm{n}}(54.1 \mathrm{~kg} / \mathrm{mol})$ was higher than the theoretical value. The low initiation efficiency $\left(I^{*}=19.0 \%\right)$ was presumably caused by the stable $\mathrm{NHC} / \mathrm{Al}$ adduct, which is difficult to dissociate in the presence of monomers so as to generate free NHC for initiating polymerization. A reversed addition sequence by premixing $\mathrm{Al}(\mathrm{BHT})_{2} \mathrm{Me}$ and ${ }^{(\mathrm{Ph}) \mathrm{Et}} \mathrm{NHC}$ first and then adding MMA resulted in low active polymerization (TOF $=200 \mathrm{~h}^{-1}$, Table 1 , Run 4 ) with an $I^{*}$ of only $3.0 \%$, indicating the importance of preventing the contact of $\mathrm{Al}(\mathrm{BHT})_{2} \mathrm{Me}$ and $\mathrm{NHC}$ before initiation. Nevertheless, the problem of low $I^{*}$ can be solved by decreasing the catalyst loading to $0.2 \mathrm{~mol} \%$, which leads to polymerization with an $I^{*}$ of $50.0 \%$ (Table 1, Run 5). As shown in Figure 1, monomer conversion increases linearly with polymerization time after an initial induction period $(1.2 \mathrm{~min})$. The quantitative conversion can be achieved in $16 \mathrm{~min}$, affording the polymer a TOF value of $1875 \mathrm{~h}^{-1}$. It is worth noting that a perfectly linear growth of $M_{n}$ with increasing monomer conversion was observed while an extremely narrow dispersity remained $(~ Đ=1.04 \sim 1.11$, Table S1, Figure S1), indicative of controlled polymerization with a living characteristic. Moreover, the MALDI-TOF MS spectrum of the PMMA oligomer produced by $\mathrm{Al}(\mathrm{BHT})_{2} \mathrm{Me} /{ }^{(\mathrm{Ph}) \mathrm{Et}} \mathrm{NHC}$ showed only one series of mass ions (Figure 2 ). A plot of $m / z$ values of this 
series vs. the number of monomer repeat units $(x)$ yielded a straight line with a slope of 100.0 (the mass of MMA) and an intercept of 277.6 corresponding to ${ }^{(\mathrm{Ph}) \mathrm{Et}} \mathrm{NHC} / \mathrm{H}$ chain ends, supporting that the polymerization is initiated by ${ }^{(\mathrm{Ph}) \mathrm{Et}} \mathrm{NHC}$ and proceeds through a conjugate-addition mechanism. Note that a six-membered lactone chain end caused by backbiting termination was undetectable in the MALDI-TOF MS spectrum, demonstrating the successful suppression of backbiting termination by introducing sterically hindered $\mathrm{Al}(\mathrm{BHT})_{2} \mathrm{Me} \mathrm{LA}$ as anticipated, thus giving rise to the controlled polymerization with a living characteristic.

Table 1. Selected results of polymerizations by $\mathrm{Al}(\mathrm{BHT})_{2} \mathrm{Me} / \mathrm{NHC} \mathrm{LPs}^{1}$.

\begin{tabular}{|c|c|c|c|c|c|c|c|c|c|c|}
\hline Run & LB & LA & $\begin{array}{c}\text { Monomer } \\
\text { (M) }\end{array}$ & M/LA/LB & Solvent & $\begin{array}{l}\text { Time } \\
\text { (min) }\end{array}$ & $\begin{array}{l}\text { Conv. } \\
(\%)^{2}\end{array}$ & $\begin{array}{l}M_{\mathrm{n}}{ }^{3} \\
(\mathrm{~kg} / \mathrm{mol})\end{array}$ & $\oplus^{3}$ & $\begin{array}{l}I^{* 4} \\
(\%)\end{array}$ \\
\hline 1 & 1 & - & MMA & $100 /-/ 1$ & TOL & 1440 & 0 & - & - & - \\
\hline 2 & - & $\mathrm{Al}(\mathrm{BHT})_{2} \mathrm{Me}$ & MMA & $100 / 1 /-$ & TOL & 1440 & 0 & - & - & - \\
\hline 3 & 1 & $\mathrm{Al}(\mathrm{BHT})_{2} \mathrm{Me}$ & MMA & $100 / 2 / 1$ & TOL & 3 & 100 & 54.1 & 1.11 & 19.0 \\
\hline $4^{5}$ & 1 & $\mathrm{Al}(\mathrm{BHT})_{2} \mathrm{Me}$ & MMA & $100 / 2 / 1$ & TOL & 30 & 100 & 343.2 & 1.14 & 3.00 \\
\hline 5 & 1 & $\mathrm{Al}(\mathrm{BHT})_{2} \mathrm{Me}$ & MMA & $500 / 2 / 1$ & TOL & 16 & 100 & 102.7 & 1.06 & 50.0 \\
\hline 6 & 1 & $\mathrm{Al}(\mathrm{BHT})_{2} \mathrm{Me}$ & MMA & $500 / 3 / 1$ & TOL & 10 & 100 & 82.5 & 1.13 & 60.6 \\
\hline 7 & 1 & $\mathrm{Al}(\mathrm{BHT})_{2} \mathrm{Me}$ & MMA & $500 / 2 / 1$ & DCM & 25 & 100 & 127.9 & 1.07 & 39.1 \\
\hline 8 & 1 & $\mathrm{~B}\left(\mathrm{C}_{6} \mathrm{~F}_{5}\right)_{3}$ & MMA & $100 / 2 / 1$ & TOL & 75 & 99 & 15.8 & 1.48 & 65.2 \\
\hline 9 & 1 & $\mathrm{Al}\left(\mathrm{C}_{6} \mathrm{~F}_{5}\right)_{3}$ & MMA & $100 / 2 / 1$ & TOL & 1440 & 0 & - & - & - \\
\hline 10 & 1 & $\mathrm{AlMe}_{3}$ & MMA & $100 / 2 / 1$ & TOL & 1440 & 0 & - & - & - \\
\hline 11 & 1 & $\mathrm{AlEt}_{3}$ & MMA & $100 / 2 / 1$ & TOL & 1440 & 19.6 & - & - & - \\
\hline 12 & 1 & $\mathrm{Al}^{i} \mathrm{Bu}_{3}$ & MMA & $100 / 2 / 1$ & TOL & 1440 & 99.8 & 106 & 1.47 & 9.70 \\
\hline 13 & 2 & $\mathrm{Al}(\mathrm{BHT})_{2} \mathrm{Me}$ & MMA & $500 / 2 / 1$ & TOL & 30 & 98 & 130.6 & 1.07 & 38.0 \\
\hline 14 & 3 & $\mathrm{Al}(\mathrm{BHT})_{2} \mathrm{Me}$ & MMA & $250 / 2 / 1$ & TOL & 34 & 93.2 & $258.0^{6}$ & $1.08^{6}$ & 9.03 \\
\hline 15 & 1 & $\mathrm{Al}(\mathrm{BHT})_{2} \mathrm{Me}$ & ${ }^{n}$ BuMA & $500 / 2 / 1$ & TOL & 20 & 100 & 128.9 & 1.18 & 55.0 \\
\hline 16 & 1 & $\mathrm{Al}(\mathrm{BHT})_{2} \mathrm{Me}$ & MMBL & $500 / 2 / 1$ & $\mathrm{DCM}+\mathrm{TOL}^{7}$ & 40 & 98.5 & 133.0 & 1.04 & 41.5 \\
\hline $17^{8}$ & 1 & $\mathrm{Al}(\mathrm{BHT})_{2} \mathrm{Me}$ & $\mathrm{MMA} /{ }^{n} \mathrm{BuMA}$ & $(400+250) / 2 / 1$ & TOL & $\begin{array}{l}16 \\
10\end{array}$ & 100 & $\begin{array}{c}87.4 \\
105.5\end{array}$ & $\begin{array}{l}1.13 \\
1.09\end{array}$ & - \\
\hline
\end{tabular}

${ }^{1}$ Conditions: $\mathrm{M} / \mathrm{LA} / \mathrm{LB}=100 / 2 / 1: \mathrm{LB}=37.4 \mathrm{umol}$, $[\mathrm{MMA}]=1.56 \mathrm{M}, \mathrm{M} / \mathrm{LA} / \mathrm{LB}=500 / 2 / 1: \mathrm{LB}=18.7$ umol, $[\mathrm{MMA}]=0.94 \mathrm{M}, 250 / 2 / 1: \mathrm{LB}=37.4 \mathrm{umol},[\mathrm{MMA}]=0.94 \mathrm{M} .{ }^{2}$ Monomer conversions were measured by ${ }^{1} \mathrm{H}$ NMR spectra. ${ }^{3}$ Number-average molecular weight $\left(M_{n}\right)$ and dispersity $\left(\Xi=M_{\mathrm{w}} / M_{\mathrm{n}}\right)$ were determined by GPC at $40{ }^{\circ} \mathrm{C}$ in THF relative to PMMA standards. ${ }^{4}$ Initiation efficiency $\left(I^{*}\right)=M_{\mathrm{n}}($ calcd. $) / M_{\mathrm{n}}(\operatorname{exptl})$, where $M_{\mathrm{n}}($ calcd. $)=\mathrm{MW}(\mathrm{M}) \times$ $[\mathrm{M}] /[\mathrm{LB}] \times$ conversion $(\%)+\mathrm{MW}$ (chain-end groups). ${ }^{5}$ The polymerization was carried out by premixing LA and LB first followed by adding MMA. ${ }^{6}$ GPC trace showed a small (ca. 9\%) high MW shoulder peak. ${ }^{7}$ The polymerization was started by the addition of an NHC solution in toluene to DCM solution of $\gamma \mathrm{MMBL}$ and Al(BHT) ${ }_{2}$ Me. ${ }^{8}$ Diblock copolymer was prepared by initiating MMA block first followed by adding ${ }^{n}$ BuMA.

When the amount of $\mathrm{Al}(\mathrm{BHT})_{2} \mathrm{Me}$ was increased to 3 equivalent relative to ${ }^{(\mathrm{Ph}) \mathrm{Et}} \mathrm{NHC}$, the $I^{*}$ and TOF values of the polymerization further enhanced to $60.6 \%$ and $3000 \mathrm{~h}^{-1}$, respectively, affording the polymer with a narrow $Đ$ value of 1.13 (Table 1, Run 6). Changing the solvent from toluene to more polar DCM decreased both the activity and the $I^{*}$ (Table 1, Run 7), as NHCs are known to decompose in DCM over time. In addition, polymerization by the other LAs in conjunction with (Ph)Et NHC LB, has also been studied. The polymerization became sluggish and uncontrolled when replacing $\mathrm{Al}(\mathrm{BHT})_{2} \mathrm{Me}$ with $\mathrm{B}\left(\mathrm{C}_{6} \mathrm{~F}_{5}\right)_{3}\left(\mathrm{TOF}=79.2 \mathrm{~h}^{-1}\right)$, producing the polymer with broader dispersity $(\boxplus=1.48)$, though the $I^{*}$ of the polymerization was higher under the same conditions (Table 1, Run 8 vs. 3). No polymerization occurred within $24 \mathrm{~h}$ when the strong Lewis-acidic $\operatorname{Al}\left(\mathrm{C}_{6} \mathrm{~F}_{5}\right)_{3}$ was used as an LA for MMA polymerization (Table 1, Run 9). Switching to the alkyl aluminums, $\mathrm{AlMe}_{3}$ and $\mathrm{AlEt}_{3}$ with weak Lewis acidity and less steric hindrance were inactive for LPP up to $24 \mathrm{~h}$ (Table 1, Runs 10-11), while the polymerization by more sterically demanding $\mathrm{Al}^{i} \mathrm{Bu}_{3}$ exhibited very low activity $\left(\mathrm{TOF}=4.1 \mathrm{~h}^{-1}\right.$ ) and an $I^{*}$ of $9.70 \%$ (Table 1 , Run 12$)$, producing the polymer with broad dispersity $(\nexists=1.47)$. These results indicated the unicity of the $\mathrm{Al}(\mathrm{BHT})_{2} \mathrm{Me}$-based LA when coupled with the (Ph)Et NHC LB for highly active and controlled polymerization of MMA. 


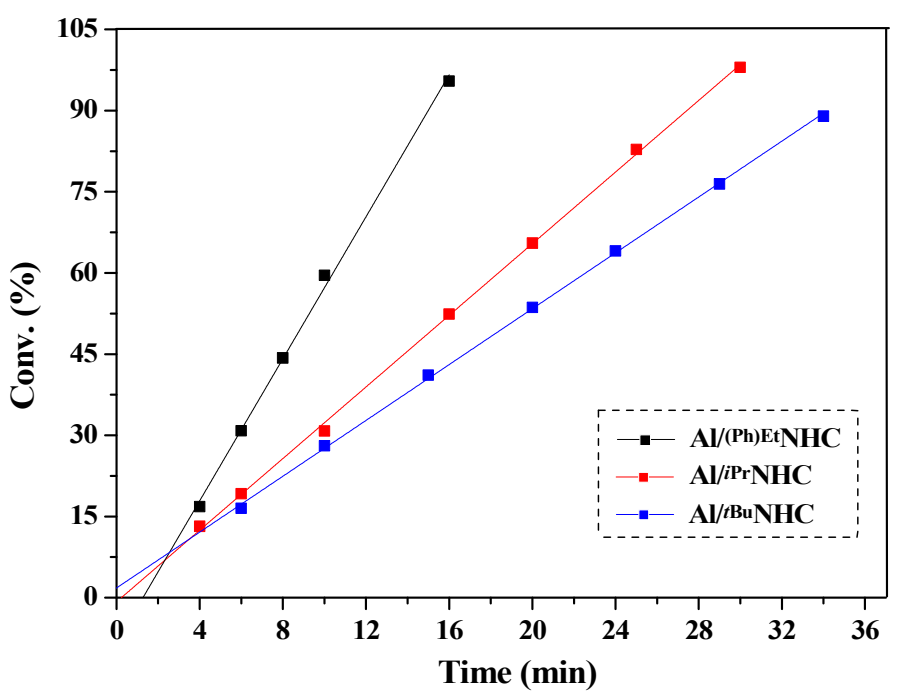

Figure 1. Conversion-time plots for the MMA polymerization by different Lewis pairs (LPs) in toluene at room temperature (RT).

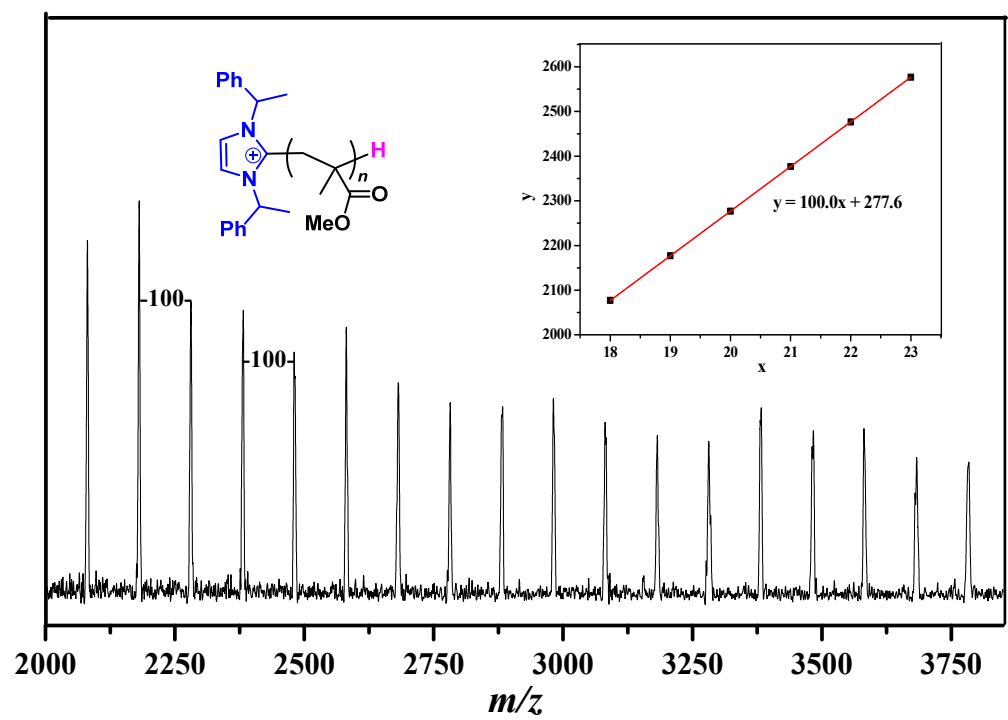

Figure 2. MALDI-TOF MS analysis for PMMA oligomers produced by $\mathrm{Al}(\mathrm{BHT})_{2} \mathrm{Me} /{ }^{(\mathrm{Ph}) \mathrm{Et}} \mathrm{NHC}$ in toluene at RT. Inset: a plot of $m / z$ values (y) vs. the number of MMA repeat units (x).

Besides ${ }^{(\mathrm{Ph}) \mathrm{Et}} \mathrm{NHC}$, two other NHCs, ${ }^{i \mathrm{Pr}} \mathrm{NHC}$ and ${ }^{\mathrm{tBu}} \mathrm{NHC}$, were also utilized as LBs to examine the effect of the NHC structure on $\mathrm{Al}(\mathrm{BHT})_{2}$ Me-based LPP. As shown in Figure 1, the monomer conversions in both LP systems also increase linearly with polymerization time after an initial induction period ( ${ }^{i P r} \mathrm{NHC}: 0.3 \mathrm{~min},{ }^{t \mathrm{Bu}} \mathrm{NHC}: \mathrm{ca} .0 \mathrm{~min}$ ). The activities and $I^{*}$ values of the polymerizations follow the order of ${ }^{t \mathrm{Bu}} \mathrm{NHC}\left(411 \mathrm{~h}^{-1}, 9 \%\right)<{ }^{i \operatorname{Pr}} \mathrm{NHC}\left(980 \mathrm{~h}^{-1}, 38 \%\right)<{ }^{(\mathrm{Ph}) \mathrm{Et}} \mathrm{NHC}\left(1875 \mathrm{~h}^{-1}, 50 \%\right)$ (Table 1 , Run 5 vs. 13 vs. 14). The most nucleophilic ${ }^{\mathrm{tBu}} \mathrm{NHC}$ as an LB for LPP exhibited the lowest activity and $I^{*}$, probably due to the extremely high steric stress between the bulky ${ }^{t \mathrm{Bu}} \mathrm{NHC}$ and steric demanding $\mathrm{MMA} \rightarrow \mathrm{Al}(\mathrm{BHT})_{2} \mathrm{Me}$ adduct that prevents the formation of zwitterionic species. On the other hand, compared to ${ }^{(\mathrm{Ph}) \mathrm{Et}} \mathrm{NHC}$, less sterically hindered ${ }^{i \mathrm{Pr}} \mathrm{NHC}$-based LP exhibited lower activity and $I^{*}$, presumably caused by the formation of a more stable CLP, which is more difficult to dissociate so as to generate free NHC for initiating polymerization. Hence, it appears that the steric hindrance of ${ }^{\mathrm{Ph}) \mathrm{Et}} \mathrm{NHC}$ has a fine balance between the ability to attack the monomer and the propensity to dissociate from the CLP, thus enabling the highest activity and $I^{*}$ in ${ }^{(\mathrm{Ph}) \mathrm{Et}} \mathrm{NHC} / \mathrm{Al}(\mathrm{BHT}){ }_{2} \mathrm{Me}$-mediated 
polymerization. It is noteworthy that the polymerization by ${ }^{i \operatorname{Pr}} \mathrm{NHC} / \mathrm{Al}(\mathrm{BHT})_{2} \mathrm{Me}$ is also very controlled with a living characteristic, similar to the ${ }^{(\mathrm{Ph}) \mathrm{Et}} \mathrm{NHC} / \mathrm{Al}(\mathrm{BHT})_{2} \mathrm{Me}$ system, as confirmed by a linear growth of $M_{\mathrm{n}}$ with increasing monomer conversion as well as maintained extremely narrow dispersity ( $Đ$ : 1.06 1.13, Figure 3, Table S2). Different from ${ }^{(\mathrm{Ph}) \mathrm{Et}} \mathrm{NHC}$ and ${ }^{i \mathrm{Pr}} \mathrm{NHC}$-based LP systems, ${ }_{t \mathrm{Bu}} \mathrm{NHC} / \mathrm{Al}(\mathrm{BHT})_{2} \mathrm{Me}$ promoted uncontrolled polymerization, affording the polymer with a bimodal molecular weight distribution (Figure S2). In terms of the stereoselectivity of these LPP systems, the use of the sterically demanding $\mathrm{Al}(\mathrm{BHT})_{2} \mathrm{Me} \mathrm{LA} \mathrm{did} \mathrm{not} \mathrm{noticeably} \mathrm{affect} \mathrm{the} \mathrm{stereoselectivity,}$ and the PMMAs produced at RT were typically syndio-rich $(\sim 70 \% \mathrm{rr})$.

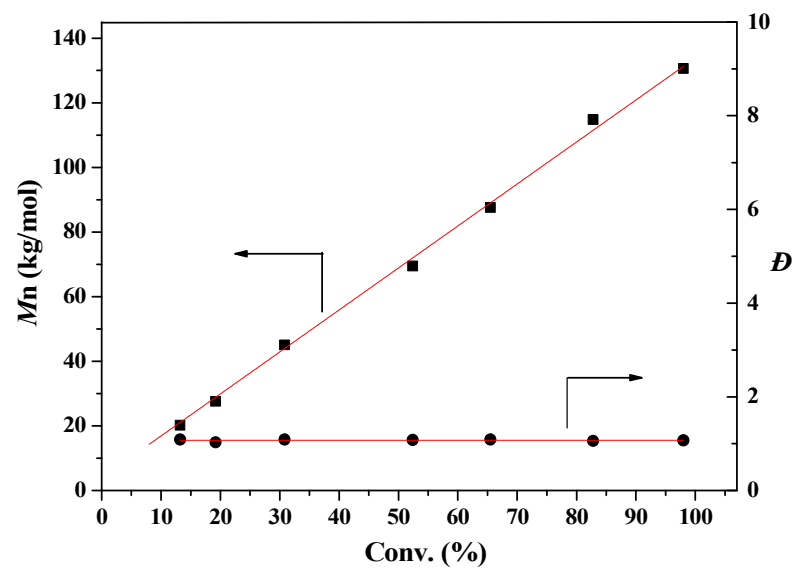

(A)

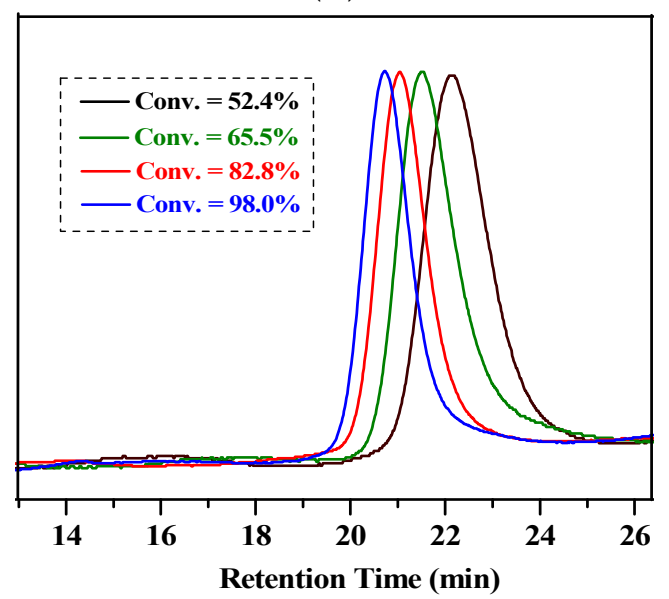

(B)

Figure 3. (A) Plots of $M_{\mathrm{n}}$ and $\oslash$ vs. monomer conversion (\%) for the MMA polymerization by $i \mathrm{Pr} \mathrm{NHC} / \mathrm{Al}(\mathrm{BHT})_{2} \mathrm{Me}$. (B) GPC traces for PMMAs produced at different monomer conversions.

Following a successful polymerization protocol developed for MMA polymerization, the ${ }^{(\mathrm{Ph}) \mathrm{Et}} \mathrm{NHC} / \mathrm{Al}(\mathrm{BHT})_{2} \mathrm{Me} \mathrm{LP}$ system was also found to be highly active and controlled for the polymerization of the sterically encumbered ${ }^{n} \mathrm{BuMA}\left(\mathrm{TOF}=1500 \mathrm{~h}^{-1}\right)$ and biorenewable $\gamma \mathrm{MMBL}$ $\left(\right.$ TOF $\left.=750 \mathrm{~h}^{-1}\right)$, showing moderate $I^{*}$ values $(41.5 \sim 55.0 \%)$ and producing polymers with narrow dispersities (1.04 1.18), though their activities were lower than those of MMA polymerization (Table 1, Run 15 vs. 16 vs. 5). Moreover, the living characteristic of LPP by ${ }^{(\mathrm{Ph}) \mathrm{Et}} \mathrm{NHC} / \mathrm{Al}(\mathrm{BHT})_{2} \mathrm{Me}$ enabled the synthesis of well-defined diblock copolymers. The sequential addition as a result of polymerizing MMA first with MMA $/ \mathrm{Al}(\mathrm{BHT}){ }_{2} \mathrm{Me} /(\mathrm{Ph}) \mathrm{Et} N H C=400 / 1 / 2$ without quenching and subsequently with another 250 equivalent of ${ }^{n}$ BuMA afforded the successfully well-defined diblock copolymer PMMA- $b$-P ${ }^{n}$ BuMA (Table 1, Run 17), as evidenced by GPC traces (Figure S3), where PMMA produced 
first $\left(M_{\mathrm{n}}=87.4 \mathrm{~kg} / \mathrm{mol}, \Xi=1.13\right)$ shifted to a higher molecular weight region while the narrow dispersity remained $\left(M_{\mathrm{n}}=105.5 \mathrm{~kg} / \mathrm{mol}, \oslash=1.09\right)$.

\section{Experimental Section}

\subsection{Materials, Reagents, and Methods}

All synthesis and manipulations of air- and moisture-sensitive materials were carried out in flamed Schlenk-type glassware on a dual-manifold Schlenk line, on a high-vacuum line, or in an argon-filled glovebox. HPLC-grade organic solvents were first sparged extensively with nitrogen as they were placed into $20 \mathrm{~L}$ solvent reservoirs and then dried via passage through activated alumina (for dichloromethane (DCM)) and then via passage through Q-5 supported copper catalyst stainless steel columns [for toluene (TOL)]. Methyl methacrylate (MMA) was purchased from Aldrich Chemical Co. (Shanghai, China), while butyl methacrylate ( $\left.{ }^{n} \mathrm{BuMA}\right)$ and $\gamma$-methyl- $\alpha$-methylene- $\gamma$-butyrolactone $(\gamma \mathrm{MMBL})$ were purchased from TCI Shanghai. These monomers were first degassed and dried over $\mathrm{CaH}_{2}$ overnight, followed by vacuum distillation. MMA was further purified by titration with neat tri(n-octyl)aluminum to a yellow end point and distillation under reduced pressure [38]. The purified monomers were stored in brown bottles inside a glovebox freezer at $-30{ }^{\circ} \mathrm{C}$ for further use. Triisobutylaluminum $\left(\mathrm{Al}^{i} \mathrm{Bu}, 1.0 \mathrm{M}\right.$ in hexanes) was purchased from JEK Chemical Co. (Shanghai, China), while trimethylaluminum (AlMe $3,1.0 \mathrm{M}$ in heptane) and triethylaluminum ( $\mathrm{AlEt}_{3}, 0.6 \mathrm{M}$ in heptane) were purchased from Acros Chemical Co. (Shanghai, China), which were all used as received. 2,6-di-tert-Butyl-4-methylphenol (BHT-H) was purchased from Macklin and recrystallized from hexanes prior to use. Literature procedures were used to prepare $\mathrm{MeAl}(\mathrm{BHT})_{2}$ [39]. Tris(pentafluorophenyl) borane $\left(\mathrm{B}\left(\mathrm{C}_{6} \mathrm{~F}_{5}\right)_{3}\right)$ was purchased from Aldrich Chemical $C_{0}$. and further purified via sublimation under vacuum. Tris(pentafluorophenyl)alane $\left(\mathrm{Al}\left(\mathrm{C}_{6} \mathrm{~F}_{5}\right)_{3}\right)$, as a (toluene $)_{0.5}$ adduct, was prepared by ligand exchange reaction between $\mathrm{B}\left(\mathrm{C}_{6} \mathrm{~F}_{5}\right)_{3}$ and $\mathrm{AlMe}_{3}$ [40]. N-Heterocyclic carbenes (NHCs), including 1,3-bis-(1-phenylethyl)imidazolin-2-ylidene $\left({ }^{(\mathrm{Ph}) \mathrm{Et}} \mathrm{NHC}\right)$ [41] and 1,3-diisopropal-4,5-dimethylimidazol-2-ylidene $\left({ }^{i \operatorname{Pr}} \mathrm{NHC}\right)$ [42], were synthesized according to literature procedures, while 1,3-di-tert-butylimidazol-2-ylidene ( $\left.{ }^{t \mathrm{Bu}} \mathrm{NHC}\right)$ was purchased from TCI Shanghai. Benzene- $d_{6}$ was dried over a sodium/potassium alloy and vacuum-distilled or filtered.

\subsection{Stoichiometric Reaction of $A l(B H T)_{2} M e$ with $M M A$ and In Situ Generation of $M M A \rightarrow A l(B H T)_{2} M e$ Adduct}

To a benzene- $d_{6}(0.5 \mathrm{~mL})$ solution of MMA $(3.5 \mathrm{mg}, 0.035 \mathrm{mmol})$ in a J-Young NMR tube, $\mathrm{Al}(\mathrm{BHT}){ }_{2} \mathrm{Me}(16.8 \mathrm{mg}, 0.035 \mathrm{mmol})$ was added. The mixture was allowed to react for $10 \mathrm{~min}$ before ${ }^{1} \mathrm{H}-\mathrm{NMR}$ measurement, which indicated the formation of MMA $\rightarrow \mathrm{Al}(\mathrm{BHT}){ }_{2} \mathrm{Me}$ adduct. ${ }^{1} \mathrm{H}-\mathrm{NMR}$ $\left(400 \mathrm{MHz}\right.$, benzene- $\left.d_{6}, 25^{\circ} \mathrm{C}\right): \delta 7.18(\mathrm{~s}, 4 \mathrm{H}, \mathrm{Ar}-H), 6.20\left(\mathrm{~s}, 1 \mathrm{H},=\mathrm{CH}_{2}\right), 5.11\left(\mathrm{~s}, 1 \mathrm{H},=\mathrm{CH}_{2}\right), 3.17(\mathrm{~s}, 3 \mathrm{H}$, $\left.-\mathrm{OCH}_{3}\right), 2.32\left(\mathrm{~s}, 6 \mathrm{H}, \mathrm{Ar}-\mathrm{CH}_{3}\right), 1.56\left(\mathrm{~s}, 36 \mathrm{H},-{ }^{t} \mathrm{Bu}\right), 1.39\left(\mathrm{~s}, 3 \mathrm{H},-\mathrm{CH}_{3}\right), 0.01\left(\mathrm{~s}, 3 \mathrm{H}, \mathrm{Al}-\mathrm{CH}_{3}\right)$.

\subsection{Stoichiometric Reaction of $\mathrm{Al}(\mathrm{BHT})_{2} \mathrm{Me}$ with (Ph)EtNHC and In Situ Generation of} $(\mathrm{Ph}) \mathrm{EtNHC} \rightarrow \mathrm{Al}(\mathrm{BHT})_{2} \mathrm{Me}$ Adduct

To a benzene- $d_{6}(0.5 \mathrm{~mL})$ solution of ${ }^{(\mathrm{Ph}) \mathrm{Et}} \mathrm{NHC}(5.0 \mathrm{mg}, 0.018 \mathrm{mmol})$ in a J-Young NMR tube, $\mathrm{Al}(\mathrm{BHT})_{2} \mathrm{Me}(8.7 \mathrm{mg}, 0.018 \mathrm{mmol})$ was added. The mixture was allowed to react for $10 \mathrm{~min}$ before ${ }^{1} \mathrm{H}-\mathrm{NMR}$ measurement, which indicated the formation of ${ }^{(\mathrm{Ph}) \mathrm{Et}} \mathrm{NHC} \rightarrow \mathrm{Al}(\mathrm{BHT})_{2}$ Me adduct as two isomers $\mathrm{A}$ (major) and B (minor) in a 6:4 ratio. ${ }^{1} \mathrm{H}-\mathrm{NMR}\left(400 \mathrm{MHz}\right.$, benzene- $\left.d_{6}, 25^{\circ} \mathrm{C}\right): \delta 6.98 \sim 7.20\left(\mathrm{~m},{ }^{(\mathrm{Ph}) \mathrm{Et}} \mathrm{NHC}\right.$ : $\left.8 \mathrm{H}, \mathrm{Ph}-H, \mathrm{Al}(\mathrm{BHT}){ }_{2} \mathrm{Me}: 4 \mathrm{H}, \mathrm{Ar}-H\right), 6.61\left(\mathrm{~d}, J=8.0 \mathrm{~Hz},{ }^{(\mathrm{Ph}) \mathrm{Et}} \mathrm{NHC}: 2 \mathrm{H}, \mathrm{Ph}-H\right), 6.42(\mathrm{~s}, 0.7 \mathrm{H}, \mathrm{B}$ isomer, $-\mathrm{CH}=\mathrm{CH}-), 6.32(\mathrm{~s}, 1.3 \mathrm{H}, \mathrm{A}$ isomer, $-\mathrm{CH}=\mathrm{CH}-), 6.04\left(\mathrm{q}, J=8.0 \mathrm{~Hz}, 0.7 \mathrm{H}, \mathrm{B}\right.$ isomer, $\left.>\mathrm{CHCH}_{3}\right)$, $5.98\left(\mathrm{q}, J=8.0 \mathrm{~Hz}, 1.3 \mathrm{H}, \mathrm{A}\right.$ isomer, $\left.>\mathrm{CHCH}_{3}\right), 2.40\left(\mathrm{~d}, J=8.0 \mathrm{~Hz}, 6 \mathrm{H},>\mathrm{CHCH}_{3}\right), 1.33 \sim 1.59(\mathrm{~m}, 42 \mathrm{H}$, ${ }_{-}^{t} \mathrm{Bu}$ and $\left.\mathrm{Ar}-\mathrm{CH}_{3}\right),-0.21\left(\mathrm{~s}, 3 \mathrm{H}, \mathrm{Al}-\mathrm{CH}_{3}\right)$. 


\subsection{General Polymerization Procedures}

Polymerizations were performed either in $25 \mathrm{~mL}$ flame-dried Schlenk flasks interfaced to the dual-manifold Schlenk line for runs using external temperature bath or in $20 \mathrm{~mL}$ glass reactors inside the glovebox for ambient temperature (ca. $25^{\circ} \mathrm{C}$ ) runs. In a typical polymerization procedure, a predetermined amount of LA was first dissolved in a predetermined amount of monomer [M] and solvent inside a glovebox. The polymerization was started by the rapid addition of an LB solution in a solvent via a gastight syringe to the above-mentioned mixture containing the LA and monomer under vigorous stirring. The amount of the monomer was fixed for the varied $[\mathrm{M}] /[\mathrm{LB}]$ ratio runs. After the measured time interval, a $0.2 \mathrm{~mL}$ aliquot was taken from the reaction mixture via syringe and quickly quenched into a $2 \mathrm{~mL}$ vial containing $0.4 \mathrm{~mL}$ of undried "wet" $\mathrm{CDCl}_{3}$ stabilized by 250 ppm of BHT-H; the quenched aliquots were later analyzed by ${ }^{1} \mathrm{H}-\mathrm{NMR}$ to obtain the percent monomer conversion data. After the polymerization was stirred for the stated reaction time, the polymer was immediately precipitated into $200 \mathrm{~mL}$ of methanol, stirred for $1 \mathrm{~h}$, filtered, washed with methanol, and dried in a vacuum oven at $50{ }^{\circ} \mathrm{C}$ overnight to a constant weight.

\subsection{Polymer Characterizations}

NMR spectra were recorded on a Varian $400 \mathrm{MHz}$ spectrometer. Chemical shifts for ${ }^{1} \mathrm{H}$ and ${ }^{13} \mathrm{C}$ spectra were referenced to internal solvent resonances and are reported as parts per million relative to $\mathrm{SiMe}_{4}$. Polymer number-average molecular weights $\left(M_{n}\right)$ and molecular weight distributions $\left(Ð=M_{\mathrm{w}} / M_{\mathrm{n}}\right.$ ) were measured by gel permeation chromatography (GPC) analyses carried out at $40^{\circ} \mathrm{C}$ and a flow rate of $1.0 \mathrm{~mL} / \mathrm{min}$, with THF as the eluent, on a Waters 1515 GPC instrument equipped with a Waters 2414 refractive-index detector and three Waters Styragel HR-3,4,5 columns connected in series. The instrument was calibrated with 10 PMMA standards, and chromatograms were processed with Waters Empower software (Version 3, Waters Ireland, Dublin, Ireland). The isolated low molecular weight samples were analyzed by matrix-assisted laser desorption/ionization time-of-flight mass spectroscopy (MALDI-TOF MS); the experiment was performed on an Shimadzu Biotech Axima Performance MALDI-TOF mass spectrometer (Kyoto, Japan) operated in positive ion reflector mode using an Nd:YAG laser at $355 \mathrm{~nm}$ and a $25 \mathrm{kV}$ accelerating voltage. A thin layer of a $1 \%$ NaI solution was first deposited on the target plate, followed by $0.6 \mu \mathrm{L}$ of both sample and matrix (dithranol, $10 \mathrm{mg} / \mathrm{mL}$ in $50 \% \mathrm{ACN}, 0.1 \% \mathrm{TFA}$ ). External calibration was done using a peptide calibration mixture (4-6 peptides) on a spot adjacent to the sample.

\section{Conclusions}

In summary, we have established an effective strategy for controlled and efficient Lewis pair polymerizations of conjugated polar alkenes including MMA, ${ }^{n}$ BuMA, and $\gamma \mathrm{MMBL}$ under mild conditions. Success is attributable to the judicious selection of cooperative LAs and LBs: the introduction of sterically demanding $\mathrm{Al}(\mathrm{BHT})_{2} \mathrm{Me}$ as an LA can completely shut down intramolecular backbiting termination, and the utilization of a strong nucleophile NHC as an LB ensures high activity and acceptable initiation efficiency. Investigation into the scope of LAs showed that an $\mathrm{Al}(\mathrm{BHT})_{2} \mathrm{Me}$-based LA is unique for such LPP, while the other less sterically hindered LAs, such as $\mathrm{Al}\left(\mathrm{C}_{6} \mathrm{~F}_{5}\right)_{3}, \mathrm{~B}\left(\mathrm{C}_{6} \mathrm{~F}_{5}\right)_{3}, \mathrm{AlMe}_{3}, \mathrm{AlEt}_{3}$, and $\mathrm{Al}^{i} \mathrm{Bu}_{3}$, did not lead to any polymer formation or resulted in uncontrolled/low active polymerization. In this study, compared to the ${ }^{i \operatorname{Pr}} \mathrm{NHC}$ and ${ }^{t \mathrm{Bu}} \mathrm{NHC}$, the ${ }^{(\mathrm{Ph}) \mathrm{Et}} \mathrm{NHC}$-based LP coupled with $\mathrm{Al}(\mathrm{BHT})_{2} \mathrm{Me}$, which showed a fine balance between the ability to attack monomers and the propensity to dissociate from CLPs, exhibited the highest activity (TOF up to $3000 \mathrm{~h}^{-1}$ ) and an initiation efficiency up to $60.6 \%$. Note that the ${ }^{(\mathrm{Ph}) \mathrm{Et}} \mathrm{NHC} / \mathrm{Al}(\mathrm{BHT})_{2} \mathrm{Me}$ and ${ }^{i \operatorname{Pr}} \mathrm{NHC} / \mathrm{Al}(\mathrm{BHT})_{2} \mathrm{Me} \mathrm{LP}$ systems have good control over the polymerization of MMA with a living characteristic, as evidenced by chain-extension experiments and chain-end analysis. The controlled characteristic can also be extended to ${ }^{n} \mathrm{BuMA}$ and MMBL polymerizations and enable the synthesis of well-defined diblock copolymers. 
Supplementary Materials: Supplementary materials are available online.

Acknowledgments: This work was supported by the National Natural Science Foundation of China (No. Y8502112G0), the Science and Technology Commission of Shanghai Municipality (No. 17JC1401200), and the Thousand Young Talents Plan sponsored by the Central Government of China.

Author Contributions: M.H. and X.W. conceived and designed the experiments; X.W. and Y.Z. carried out the actual experiments and interpreted the data; M.H. wrote the manuscript. All authors read and approved the final manuscript.

Conflicts of Interest: The authors declare no conflict of interest.

\section{References and Note}

1. Welch, G.C.; Juan, R.R.S.; Masuda, J.D.; Stephan, D.W. Reversible, metal-free hydrogen activation. Science 2006, 314, 1124-1126. [CrossRef] [PubMed]

2. Stephan, D.W.; Erker, G. Frustrated Lewis pairs: Metal-free hydrogen activation and more. Angew. Chem. Int. Ed. 2010, 49, 46-76. [CrossRef] [PubMed]

3. Stephan, D.W.; Erker, G. Frustrated Lewis pair chemistry: Development and perspectives. Angew. Chem. Int. Ed. 2015, 54, 6400-6441. [CrossRef] [PubMed]

4. Stephan, D.W. Frustrated Lewis pairs: From concept to catalysis. Acc. Chem. Res. 2015, 48, 306-316. [CrossRef] [PubMed]

5. $\quad$ Meng, W.; Feng, X.Q.; Du, H.F. Frustrated Lewis pairs catalyzed asymmetric metal-free hydrogenations and hydrosilylations. Acc. Chem. Res. 2018, 51, 191-201. [CrossRef] [PubMed]

6. Chen, E.Y.X. Polymerization by classical and frustrated Lewis pairs. Top. Curr. Chem. 2013, 334, $239-260$. [PubMed]

7. TOF value was calculated by the [monomer]/[catalyst] ratio divided by the reaction time when the polymerization reached typically quantitative conversion or the highest conversion reported.

8. Zhang, Y.T.; Miyake, G.M.; Chen, E.Y.X. Alane-based classical and frustrated Lewis pairs in polymer synthesis: Rapid polymerization of MMA and naturally renewable methylene butyrolactones into high-molecular-weight polymers. Angew. Chem. Int. Ed. 2010, 49, 10158-10162. [CrossRef] [PubMed]

9. Zhang, Y.T.; Miyake, G.M.; John, M.G.; Falivene, L.; Caporaso, L.; Cavallo, L.; Chen, E.Y.X. Lewis pair polymerization by classical and frustrated Lewis pairs: Acid, base and monomer scope and polymerization mechanism. Dalton Trans. 2012, 41, 9119-9134. [CrossRef] [PubMed]

10. He, J.H.; Zhang, Y.T.; Chen, E.Y.X. Synthesis of pyridine- and 2-oxazoline-functionalized vinyl polymers by alane-based frustrated Lewis pairs. Synlett 2014, 25, 1534-1538.

11. Chen, J.W.; Chen, E.Y.X. Lewis pair polymerization of acrylic monomers by $N$-heterocyclic carbenes and $\mathrm{B}\left(\mathrm{C}_{6} \mathrm{~F}_{5}\right)_{3}$. Isr. J. Chem. 2015, 55, 216-225. [CrossRef]

12. Chen, J.W.; Chen, E.Y.X. Reactivity of Amine $/ E\left(\mathrm{C}_{6} \mathrm{~F}_{5}\right)_{3}(\mathrm{E}=\mathrm{B}, \mathrm{Al})$ Lewis Pairs toward Linear and Cyclic Acrylic Monomers: Hydrogenation vs. Polymerization. Molecules 2015, 20, 9575-9590. [CrossRef] [PubMed]

13. Xu, T.Q.; Chen, E.Y.X. Probing site cooperativity of frustrated phosphine/borane Lewis pairs by a polymerization study. J. Am. Chem. Soc. 2014, 136, 1774-1777. [CrossRef] [PubMed]

14. Jia, Y.B.; Ren, W.M.; Liu, S.J.; Xu, T.Q.; Wang, Y.B.; Lu, X.B. Controlled divinyl monomer polymerization mediated by Lewis pairs: A powerful synthetic strategy for functional polymers. ACS Macro Lett. 2014, 3, 896-899. [CrossRef]

15. Xu, P.; Yao, Y.; Xu, X. Frustrated Lewis pair-like reactivity of rare-earth metal complexes: 1,4-addition reactions and polymerizations of conjugated polar alkenes. Chem. Eur. J. 2017, 23, 1263-1267. [CrossRef] [PubMed]

16. $\mathrm{Xu}, \mathrm{P.F} . ; \mathrm{Xu}, \mathrm{X}$. Homoleptic rare-earth aryloxide based Lewis pairs for polymerization of conjugated polar alkenes. ACS Catal. 2018, 8, 198-202. [CrossRef]

17. Piedra-Arroni, E.; Ladaviere, C.; Amgoune, A.; Bourissou, D. Ring-opening polymerization with $\mathrm{Zn}\left(\mathrm{C}_{6} \mathrm{~F}_{5}\right)_{2}$-based Lewis pairs: Original and efficient approach to cyclic polyesters. J. Am. Chem. Soc. 2013, 135, 13306-13309. [CrossRef] [PubMed]

18. Naumann, S.; Schmidt, F.G.; Frey, W.; Buchmeiser, M.R. Protected N-heterocyclic carbenes as latent pre-catalysts for the polymerization of $\varepsilon$-caprolactone. Polym. Chem. 2013, 4, 4172-4181. [CrossRef] 
19. Naumann, S.; Scholten, P.B.V.; Wilson, J.A.; Dove, A.P. Dual catalysis for selective ring-opening polymerization of lactones: Evolution toward simplicity. J. Am. Chem. Soc. 2015, 137, 14439-14445. [CrossRef] [PubMed]

20. Zhu, J.B.; Chen, E.Y.X. From meso-lactide to isotactic polylactide: Epimerization by B/N Lewis pairs and kinetic resolution by organic catalysts. J. Am. Chem. Soc. 2015, 137, 12506-12509. [CrossRef] [PubMed]

21. Li, X.Q.; Wang, B.; Ji, H.Y.; Li, Y.S. Insights into the mechanism for ring-opening polymerization of lactide catalyzed by $\mathrm{Zn}\left(\mathrm{C}_{6} \mathrm{~F}_{5}\right)_{2}$ /organic superbase Lewis pairs. Catal. Sci. Technol. 2016, 6, 7763-7772. [CrossRef]

22. Wang, Q.Y.; Zhao, W.C.; He, J.H.; Zhang, Y.T.; Chen, E.Y.X. Living ring-opening polymerization of lactones by $N$-heterocyclic olefin $/ \mathrm{Al}_{(}\left(\mathrm{C}_{6} \mathrm{~F}_{5}\right)_{3}$ Lewis pairs: Structures of intermediates, kinetics, and mechanism. Macromolecules 2016, 50, 123-136. [CrossRef]

23. Zhang, H.Y.; Nie, Y.Z.; Zhi, X.M.; Du, H.F.; Yang, J. Controlled ring-opening polymerization of $\alpha$-amino acid $N$-carboxy-anhydride by frustrated amine/borane Lewis pairs. Chem. Commun. 2017, 53, 5155-5158. [CrossRef] [PubMed]

24. Ji, H.Y.; Wang, B.; Pan, L.; Li, Y.S. Lewis pairs for ring-opening alternating copolymerization of cyclic anhydrides and epoxides. Green Chem. 2018, 20, 641-648. [CrossRef]

25. Yang, J.L.; Wu, H.L.; Li, Y.; Zhang, X.H.; Darensbourg, D.J. Perfectly alternating and regioselective copolymerization of carbonyl sulfide and epoxides by metal-free Lewis pairs. Angew. Chem. Int. Ed. 2017, 56, 5774-5779. [CrossRef] [PubMed]

26. Grubbs, R.B.; Grubbs, R.H. 50th Anniversary perspective: Living polymerization-Emphasizing the molecule in macromolecules. Macromolecules 2017, 50, 6979-6997. [CrossRef]

27. Aoshima, S.; Kanaoka, S. A renaissance in living cationic polymerization. Chem. Rev. 2009, 109, 5245-5287. [CrossRef] [PubMed]

28. Braunecker, W.A.; Matyjaszewski, K. Controlled/living radical polymerization: Features, developments, and perspectives. Prog. Polym. Sci. 2007, 32, 93-146. [CrossRef]

29. Matyjaszewski, K.; Xia, J. Atom transfer radical polymerization. Chem. Rev. 2001, 101, 2921-2990. [CrossRef] [PubMed]

30. Ouchi, M.; Terashima, T.; Sawamoto, M. Transition metal-catalyzed living radical polymerization: Toward perfection in catalysis and precision polymer synthesis. Chem. Rev. 2009, 109, 4963-5050. [CrossRef] [PubMed]

31. Hadjichristidis, N.; Pitsikalis, M.; Pispas, S.; Iatrou, H. Polymers with complex architecture by living anionic polymerization. Chem. Rev. 2001, 101, 3747-3792. [CrossRef] [PubMed]

32. Coates, G.W.; Hustad, P.D.; Reinartz, S. Catalysts for the living insertion polymerization of alkenes: Access to new polyolefin architectures using Ziegler-Natta chemistry. Angew. Chem. Int. Ed. 2002, 41, 2236-2257. [CrossRef]

33. He, J.H.; Zhang, Y.T.; Falivene, L.; Caporaso, L.; Cavallo, L.; Chen, E.Y.X. Chain propagation and termination mechanisms for polymerization of conjugated polar alkenes by [Al]-Based frustrated Lewis pairs. Macromolecules 2014, 47, 7765-7774. [CrossRef]

34. Jia, Y.B.; Wang, Y.B.; Ren, W.M.; Xu, T.Q.; Wang, J.; Lu, X.B. Mechanistic aspects of initiation and deactivation in $N$-heterocyclic olefin mediated polymerization of acrylates with alane as activator. Macromolecules 2014, 47, 1966-1972. [CrossRef]

35. Ning, Y.; Chen, E.Y.X. Diastereospecific ion-pairing polymerization of functionalized alkenes by metallocene/ Lewis acid hybrid catalysts. Macromolecules 2006, 39, 7204-7215. [CrossRef]

36. Knaus, M.G.M.; Giuman, M.M.; Pöthig, A.; Rieger, B. End of frustration: Catalytic precision polymerization with highly interacting Lewis pairs. J. Am. Chem. Soc. 2016, 138, 7776-7781. [CrossRef] [PubMed]

37. Ottou, W.N.; Conde-Mendizabal, E.; Pascual, A.; Wirotius, A.-L.; Bourichon, D.; Vignolle, J.; Robert, F.; Landais, Y.; Sotiropoulos, J.-M.; Miqueu, K.; et al. Organic Lewis pairs based on phosphine and electrophilic silane for the direct and controlled polymerization of methyl methacrylate: Experimental and theoretical investigations. Macromolecules 2017, 50, 762-774. [CrossRef]

38. Allen, R.D.; Long, T.E.; Mcgrath, J.E. Preparation of high-purity, anionic-polymerization grade alkyl methacrylate monomers. Polym. Bull. 1986, 15, 127-134. [CrossRef]

39. Shreve, A.P.; Mulhaupt, R.; Fultz, W.; Calabrese, J.; Robbins, W.; Ittel, S. Sterically hindered aryloxide-substituted alkylaluminum compounds. Organometallics 1988, 7, 409-416. [CrossRef] 
40. Feng, S.; Roof, G.R.; Chen, E.Y.X. Tantalum(V)-based metallocene, half-metallocene, and non-metallocene complexes as ethylene-1-octene copolymerization and methyl methacrylate polymerization catalysts. Organometallics 2002, 21, 832-839. [CrossRef]

41. Herrmann, W.A.; Goossen, L.J.; Artus, G.R.J.; Köcher, C. Complexes of chiral imidazolin-2-ylidene ligands. Organometallics 1997, 16, 2472-2477. [CrossRef]

42. Kuhn, N.; Kratz, T. Synthesis of imidazol-2-ylidenes by reduction of imidazole-2(3H)-thiones. Synthesis 1993, 6, 561-562. [CrossRef]

Sample Availability: Samples of the compounds are available from the authors.

(C) 2018 by the authors. Licensee MDPI, Basel, Switzerland. This article is an open access article distributed under the terms and conditions of the Creative Commons Attribution (CC BY) license (http://creativecommons.org/licenses/by/4.0/). 